\title{
Impact of Bhagavad Gita Course on College Students: A Study Based on Students Feedback
}

\author{
Aruna Lolla ${ }^{1}$ \\ Published online: 14 August 2020 \\ (c) Springer Science+Business Media, LLC, part of Springer Nature 2020
}

\begin{abstract}
Srimad Bhagavad Gita, one of the most authentic scriptures of India, is being taught as an elective or regular course in various universities around the world. I have been teaching Gita in Birla Institute of Technology and Science, Hyderabad campus (BPHC) since 2012. This paper presents some feedback given by the students revealing the impact of the course on them and possible improvements in its pedagogy. Twelve batches of students (a little over 2000) have studied this course between January 2012 and May 2019. From these, 300 students volunteered in giving individual written feedback. In this elaborate write-up, they shared their experience of the course and possible improvements that they would suggest in its teaching. This includes 28 alumni, who came back to meet the author. An analysis of the student input reveals that the impact is at various levels which are broadly placed under three categories here: (1) an immediate effect of sanctity and strengthening of faith, (2) improved clarity of the mind, better focus, calm and content disposition in general and (3) long-term effect on personality traits like development of leadership and problem-solving abilities. They have also suggested a combination of traditional and modern methods of teaching for better comprehension and participation.
\end{abstract}

Keywords Bhagavad Gita course · Engineering college students · Positive attitude · Problem solving

\section{Introduction}

Srimad Bhagavad Gita, one of the most authentic scriptures of India, is being taught as an elective or regular course in various universities around the world. Many schools, colleges and universities have included the Gita in their curriculum. Top ranking professional institutes in India like IITs (Gitasupersite 2019), IIMs (Verma

Aruna Lolla

aruna@hyderabad.bits-pilani.ac.in

1 Department of Humanities and Social Sciences, Birla Institute of Technology and Science (Pilani), Hyderabad Campus, Hyderabad 500078, India 
2018) and BITS-Pilani (BITS-Pilani), Kurukshetra university (Adarsha 2012) and universities abroad like Oxford (OCHS 2019), Harvard (dnaindia.com 2012) and Seton Hall (rediff.com 2008) among many others have been teaching Gita besides other courses in humanities and social sciences. They mostly believe that the course helps in personality development and professional competence of their students.

The present generation of students is well aware of the distinction between religion and spiritual science. They are highly enthusiastic and receptive towards the application-oriented science of spirituality. These youngsters are poised to sit down and ponder over the law of Karma, understand the powers of the Mantras and even practise Yoga and meditation in their daily lives.

This paper presents some feedback given by the students who have taken the course, revealing its impact on them and possible improvements in its pedagogy. It may be also of interest to university teachers and academicians.

\section{Literature Review}

\section{Overview of Scope and Content of the Course and Logistics}

Let us take a broad overview of Srimad Bhagavad Gita to begin with. The Gita basically is a dialogue between Sri Krishna, who is an incarnation of the Divine and Arjuna, who is the principal warrior of the righteous side in the war of Mahabharata. The essential teachings of the scripture promulgate an inner renunciation of personal desires and results of our actions or work. Such renunciation leads to equanimity, accomplishes our total surrender to the Divine and supports a liberation from the dividing ego which brings us oneness. One of the prominent Yogis of twentieth century, Sri Aurobindo puts it thus:

The Gita promises us freedom for the spirit even in the midst of works and the full energies of nature, if we accept subjection of our whole being to that which is higher than the separating and limiting ego. It proposes an integral dynamic activity found on a still passivity; the largest possible action irrevocably based on an immobile calm is its secret-free expression out of a supreme inward silence. (Sri Aurobindo, The Synthesis of Yoga, Part One: The Yoga of Divine Works, III Self Surrender in Works The Way of the Gita) (Aurobindo 1999).

The syllabus of this course includes all the 18 chapters of the Gita and a brief account of the background, which is explained in two to three classes. I have been following the book mentioned below as the main or prescribed text in my classes:

Srimad Bhagavad Gita (with Sadhana Vyakhya). Trans. S. Subba Rao Hyderabad: Sri Gita Grandhalaya, 1969.

Around the age of 25 years, Sri S. Subba Rao, the author of the prescribed Gita text book for the students, came into close association with saints and sages of high order such as Ramana Maharshi and Upasni Baba. He writes in the preface of the 
book that, as a result of his service to the sages, the teachings of the Gita came flashing upon him and very soon he took them to his wife first and then to his friends. Later on, he became a Gita Pracharak (a teacher of Gita) and taught the scripture to a cross section of population for 30 years. He further acknowledges the active presence and work of the Divine Teacher, Sri Krishna, in composing this work has helped him in completing it in a short period of mere 8 months in spite of his physical handicap of blindness. Vedanta Kesari, a reputed journal in the subject comments on the book saying, "The translation is perfectly clear and intelligible. Examples drawn from everyday life and the sayings and incidents in the lives of sages add worth of the commentaries."(1961). Another textbook which is prescribed for the students is:

The Bhagavad Gita. Trans. S. Radhakrishnan. Harper Collins Publishers, 2014. ISBN: 978-81-7223-898-8

Professor S. Radhakrishnan, a prominent philosopher, educationalist and former president of India has written his translation and commentary of the Gita which was published by George Allen \& Unwin, UK in 1948. Later published in India by Harper Collins Publishers (Radhakrishnan 2014), the book is also enlightening and authentic commentary and translation in itself. The other sources prescribed for reference include "Srimadbhagavad-Gita (English)", Gita Press, Gorakhpur (India), 2004 and Sri Aurobindo's Essays on the Gita (Aurobindo 1950) among other books and papers.

\section{Previous Research}

To return to our focus area of "impact of the course", let us first take a look at the work done by other researchers on the topic. Dabas and Singh (2018) conducted a study to assess the effect of Bhagavad Gita teachings in bringing about positive psychological effects on semi-urban school students in India's National Capital Region. The results showed that the Bhagavad Gita intervention group of students showed statistically significant increased scores for the three positive variables, Hope, Optimism and Resilience, compared to control group. The authors attributed the outcomes to the fact that the Indian interventions consisted of profound thoughts and "Mantras" that the students could relate to and easily incorporate into most life situations, whereas the western positive psychology interventions required more time and expertise for effective implementation.

\section{Research Methodology}

\section{Gita at the University and Student Feedback}

Srimad Bhagavad Gita is being taught as an elective in Birla Institute of Technology and Science, Pilani campus (which started in 1964) for several decades now. However, in Hyderabad campus (BPHC) of the University, which came into existence 
much later in 2008, the author of this paper has started teaching it in January 2012 soon after she joined. It is a one semester course and the duration of each semester is around 4 months. Forty-seven students had registered for the course in the first batch which started in January 2012. The second batch had 98 students and third batch (January to May 2013) had an unprecedented number of 324 students which is highest in any elective course in Humanities in the University. Later on, the authorities of BPHC restricted the number of registrations in any course to 200 per batch. It was further reduced to 150 and then to 90 students as the number of teaching faculty increased. Looking at the number of registrations for Gita course which was mostly filled to the upper limit allowed and also the degree of attendance (which is not mandatory in BITS) as well as active student participation in the class, I felt encouraged to conduct a survey and take their feedback on the course. I was curious to know their main interest and motivation in opting for the course.

Engineering undergraduate students anywhere between their second and fourth (final) years can opt for this course. Twelve batches of students (around 2000) have studied this course between January 2012 and May 2019. These inputs were collected from the students who have completed the course or are about to complete. Not all had participated in the feedback survey which was conducted along with the regular end-semester feedback taken by the University for all the courses.

A total of 300 students volunteered in giving individual written feedback. In this elaborate write-up, they shared their experiences of the course and suggestions for possible improvements in its pedagogy. The students expressed this in their own style or kind of language. Based on the main idea or intention, similar responses were classified into similar heads.

\section{Results}

\section{Impact of the Bhagavad Gita Course}

The responses of the students regarding the impact of the Bhagavad Gita course on them are summarized in Table 1. Out of the 300 students, 242 said in that the course has given them better perception of the scheme of human life, human

Table 1 Impact of the Bhagavad Gita course on engineering undergraduate students based on feedback from them

\begin{tabular}{ll}
\hline Influence of the Bhagavad Gita course & $\begin{array}{l}\text { Number of stu- } \\
\text { dents agreeing }\end{array}$ \\
\hline $\begin{array}{l}\text { Number of students participating in the feedback } \\
\text { on the Bhagavad Gita course }\end{array}$ & 300 \\
$\begin{array}{l}\text { Overall positive effect: better perception of life, } \\
\text { clarity of thought, positive attitude }\end{array}$ & 242 \\
$\begin{array}{l}\text { Inner peace and ability to better deal with stress } \\
\text { Problem solving and satisfaction with themselves }\end{array}$ & 64 \\
$\begin{array}{l}\text { Other effects: sense of well-being, physical fitness } \\
\text { P }\end{array}$ & 27 \\
\hline
\end{tabular}


nature, clarity in thought and in decision-making, and above all an attitude of optimism and faith in the Divine.

Let us now take a closer look at specific inputs by the students. Some 64 students wrote that participation in the course bestows an inner ambience of peace and sanctity within them which helps in relieving stress and aid in generating "good thoughts" which paves way for staying calm in various life situations and also remain focused on studies. Around 90 of them reported an improvement in problem-solving ability and a feeling of satisfaction with their lives. Twenty-seven students who are well versed in Sanskrit language, who are few in number, shared their experience of chanting the verses of Gita in their solitary hours in hostel rooms and said that this has significantly improved their sense of well-being and even physical fitness. This effect is similar to playing of outdoor sports or chanting of Mantras like Lalitha and Vishnu Sahasranamam (Lolla 2018).

More than half of the respondents have written that the course is easily understandable and motivational. They felt that simple day-to-day examples in life were used in the classes which made it interesting and helped them apply certain principles of the Gita in their daily life. For example, while explaining secondary duties (optional duties), the present author once gave the example of sharing of their notes with those students who missed some class. It is not compulsory that they help the absentees, but it would be very apt and good for both parties if they did it.

\section{Suggestions to Improve the Course}

Coming to the suggestions part, 58 students wrote that student participation in the course could be increased in the form of group discussions and presentations on related aspects of studying Bhagavad Gita, and also include these in the evaluation components.

Twenty-four students felt that concepts should be explained through more of case studies and relevant anecdotes. Eleven students from the early batches suggested that the videos of mythological serials and excerpts of talks given by spiritual stalwarts can be shown to enable better understanding and appreciation of the text. This suggestion was followed for the later batches, especially after 2015.

Others (8-10 students) gave suggestions in the area of evaluation pattern, like increasing short answer type of questions, allotting marks for class attendance, etc.

The present method of teaching the course has been about $80 \%$, interactive Lecturing. As and when there is a need or feasibility like smaller class strength on a given day or inclination of the students or the teacher, group discussions and presentations are conducted in the class. For some batches, presentations were included as evaluation components. Videos of mythological serials (Ramayan by Ramanand Sagar and Mahabharat by B. R. Chopra) and excerpts of talks given by spiritual stalwarts and informative documentaries on topics like Yoga and Meditation were shown to the interested students as and when required and when permitted by time. 


\section{Discussion and Conclusion}

The Bhagavad Gita is a universal scripture. It is relevant to human lives at all times and places. Its message is meant to guide humanity in all the aspects of its existence. Sri Krishna's message guides not only our individual and social life but also leads to our spiritual upliftment and the ultimate goal of our existence, union with the Divine. Teaching this course to undergraduate students is especially useful since these youngsters have their whole life ahead of them. They can imbibe the wisdom of the Gita and lead their lives enriched by its spiritual force and light.

The study conducted by Dabas and Singh (2018) (refer to 2.2) with its substantial sample size and systematic methodology establishes a lay observation of some of my students that a "participation in the course bestows an inner ambience of peace and sanctity within them which helps in relieving stress and aid in generating "good thoughts" which paves way for staying calm in various life situations and also remain focused on studies".

Dr. Anand Kulkarni in his recent article Bhagavad Gita-A Panacea For COVID 19 published in Business World (Kulkarni 2020) highlights the necessity of the scripture thus:

As the world continues to deal with the outbreak of coronavirus, there are increasing anxiety, dilemmas, nervousness, faintheartedness among the doctors, nurses and health care workers. Dealing with coronavirus is the biggest challenge to face the health sector as it's going to ask a lot of them all. I am a doctor myself and none of us have experience of a pandemic like this...

It is also important at this stage we consider medical staff well-being and resilience and this is where Bhagavad Gita plays a big role. The religious leaders should provide this as a medicine to health care workers at this crucial time.

\section{Future Directions}

We can further research on the impact of studying the Gita by foreign students who may not be aware of or exposed to the religious-cultural background of the scripture. It would also be interesting to observe the students taking the course through standardized research tools over longer durations of time. Development of personality traits and general competence happen over a long period of time and may not be directly measurable.

An eminent scholar of the Gita, Prof. Mahadevan of the Indian Institute of Management, Bangalore (Mahadevan 2008), while addressing a seminar titled "Towards a new Paradigm of Business Management-Alternative perspectives from Ancient Indian Wisdom", observes thus:

The Bhagavad Gita is the most popular of the ancient texts not only among the Indians but also among the Westerners. Bhagavad Gita has inspired many of our national leaders and provided them strength, moral courage 
and clarity of thought with which they have led the country in its struggle. Arguably, these are important elements of making a good manager or a leader today.

Ancient education, in India as well as the world, was mostly focused on spiritual wisdom and applied fields like law, economics and arithmetic. Contemporary humanity and its intelligentsia would also benefit and flourish if its present courses of study are complemented on large scale by an imparting of spiritual wisdom drawn from highly reputed scriptures from all streams of established religions. We can then look forward to an enlightened work force and truly secular citizens of a golden era in the foreseeable future.

\section{Funding None.}

\section{Compliance with Ethical Standards}

Conflict of interest The author declares that there is no conflict of interest in this work.

Human and Animal Rights This article does not contain any studies with animals performed by any of the authors.

Informed Consent Informed consent was obtained from all individual participants included in the study.

\section{References}

Adarsha, St. (2012). A Bhagavad Gita course By Kurukshetra University. CareerIndia.com. Retrieved September 4, 2019 from https://www.careerindia.com.

Aurobindo, Sri. (1950). Essays on the Gita. New York: The Sri Aurobindo Library.

Aurobindo, Sri. (1999). The synthesis of yoga. Pondicherry: Sri Aurobindo Ashram Publication Department.

Dabas, P., \& Singh, A. (2018). Bhagavad Gita teachings and positive psychology: Efficacy for semiurban Indian students of NCR. Cogent Psychology, 5, 1-13.

Dnaindia.com. (2012). Harvard students studying the Gita, Ramayana: Univ president. Retrieved September 4, 2019 from https://www.dnaindia.com.

Gita Supersite. (2019) Srimad Bhagavad Gita. Retrieved August 31, 2019 from https://www.gitas upersite.iitk.ac.in/.

Kulkarni, A. (2020). Bhagavad Gita-A Panacea For COVID 19. Business world. Retrieved April 13, 2020 from http://www.businessworld.in/article/Bhagavad-Gita-A-Panacea-For-COVID-19/1304-2020-188898/.

Lolla, A. (2018). Mantras help the general psychological well-being of college students: A pilot study. Journal of Religion and Health, 57(1), 110-119.

Mahadevan, B. (2008). Management lesson from the Bhagavad Gita. In The Vedanta Kesari (pp. 118-121).

Radhakrishnan, S. (2014). The Bhagavad Gita. Trans. New Delhi: HarperCollins.

Rediff.com. (2008). Gita study to be mandatory at Seton Hall University. Retrieved September 4, 2019 from https://www.rediff.com.

Srimadbhagavad-Gita (English). (2004). Gorakhpur, India: Gita Press.

Subba Rao, S. (1969). Srimad Bhagavad Gita: with Sadhana Vyakhya Trans (2nd ed.). Hyderabad: Sri Gita Grandhalaya. 
The Oxford Centre for Hindu Studies. (2019). Bhagavad Gita. Retrieved September 1, 2019 from https://ochsonline.org/product/bhagavad-gita/.

The Vedanta Kesari. (1961). Ramakrishna Math, India.

Verma, P. (2018). The latest to take the plunge is IIM Ahmedabad, which is drawing lessons from the Bhagavad Gita to train future corporate leaders. The Economic Times. Retrieved August 20, 2019 from https://economictimes.indiatimes.com.

Publisher's Note Springer Nature remains neutral with regard to jurisdictional claims in published maps and institutional affiliations. 